\title{
The Impact of Working Capital Components on Firm Value in US Firms
}

\author{
Joseph Brian Cumbie ${ }^{1} \&$ John Donnellan ${ }^{2}$ \\ ${ }^{1}$ School of Business and Technology Management, Northcentral University, San Diego, USA \\ ${ }^{2}$ School of Business, New Jersey City University, Jersey City, New Jersey, USA \\ Correspondence: Joseph Brian Cumbie, School of Business and Technology Management, Northcentral \\ University, San Diego, CA 92106, United States. Tel: 1-334-663-1154. E-mail: J.Cumbie4394@email.ncu.edu
}

Received: May 29, 2017

Accepted: June 24, 2017

Online Published: July 10, 2017

doi:10.5539/ijef.v9n8p138

URL: https://doi.org/10.5539/ijef.v9n8p138

\begin{abstract}
Working capital is an important part of any businesses day-to-day operations. However, most businesses do not take into consideration that continuous investment into working capital does not maximize firm value. The specific problem addressed was firm managers that do not understand the optimal level for each component of working capital create sub-optimal value firm; leading to diminished investment returns for shareholders. For this study, 140 firms for the years 2003-2012 were selected from a stratified random sample of firms listed on the Russell 2000 index. Accounts receivable days outstanding, accounts payable days outstanding, and inventory days outstanding were regressed on economic value to determine whether a curvilinear relationship existed. All three models showed a statistically significant relationship to firm value, $\mathrm{F}(6,2268), \mathrm{p}<.01, \mathrm{R} 2=.40, \mathrm{~F}(6,2268)$, $\mathrm{p}<.01, \mathrm{R} 2=.38, \mathrm{~F}(6,2268), \mathrm{p}<.01, \mathrm{R} 2=.39$. Recommendations for firm managers included lowering accounts receivable, accounts payable, and inventory days during boom economic times while increasing accounts receivable, accounts payable, and inventory days during recessionary economic times. Consideration for future research into working-capital management and firm value should consider whether different curvilinear relationships exist between firm value and working-capital components during different economic cycles.
\end{abstract}

Keywords: accounts receivable, accounts payable, inventory, working-capital management, firm value

\section{Introduction}

Working capital is described as the lifeblood of a company (Atkas, Croci, \& Petmezas, 2015; Ek \& Guerin, 2011; Rani, 2013). In general, the definition of working capital is current assets minus current liabilities (Knauer $\&$ Wohrmann, 2013). Current assets generate a majority of cash-inflows for companies while current liabilities constitute the largest source of short-term cash outflows for companies (Knauer \& Wohrmann, 2013; Rani, 2013; Sharma \& Kumar, 2011). However, firm managers focus on the largest components of current assets (accounts receivable and inventory) minus the largest component of current liabilities (accounts payable) to understand the cash flow needs of the firm (Knauer \& Wohrmann, 2013; Rani, 2013). Previous research suggests efficient management of working capital affects profitability, and profitability affects firm value (de Almeida, \& Eid, 2014; Hill, Kelly, \& Lockhart, 2012; Kieschnick, Laplante, \& Moussawi, 2013; Knauer \& Wohrmann, 2013; Tauringana \& Afrifa, 2013; Wasiuzzaman, \& Arumugam, 2013). As each working-capital component (accounts receivable, inventory, and accounts payable) has a different effect on firm value, firm managers must be diligent in managing working capital optimally (Baños-Caballero, Garcia-Teruel, \& Martinez-Solano, 2014; Aktas et al., 2015).

To ensure smooth day-to-day operations, managers must choose the current level of investment in each component of working capital (Tauringana \& Afrifa, 2013). These day-to-day investment choices in working-capital management affect firm profitability and firm value (Tauringana \& Afrifa, 2013). Investing too little or too much in working capital increases the risk of payment default, reduced cash inflows (liquidity risk), loss of investment opportunities to grow the business, and loss of sales (Baños-Caballero et al., 2013; Enqvist, Graham, \& Nikkinen, 2014; Hill et al., 2012; Kieschnick et al, 2013; Tauringana \& Afrifa, 2013). In addition, managers must take in account firm size and sales growth opportunities because whether firm managers take a profit strategy or growth strategy can limit or increase investment into working capital (Jang \& Park, 2011, Lee, 2014). Increasing debt to fund further investment in working capital could increase bankruptcy risk for the firm 
(Jianzhou \& Ye, 2013).

Research regarding management of working capital suggests that investment in working capital follows a pattern of diminishing returns (Atkas et al., 2015; Baños-Caballero et al., 2014). Working-capital theory suggests efficient management of working capital increases firm value, while the law of diminishing returns suggests increased investment in working capital does not supply continuously increasing returns on capital employed (Atkas et al., 2015; Baños-Caballero et al., 2014; Knauer \& Wohrmann, 2013). If increased risks are associated with decreased rewards and if firm managers attempt to reach an optimal level of working capital, a curvilinear relationship should exist between working-capital components and firm value (Aktas et al., 2015, Baños-Caballero et al., 2014; Knauer \& Wohrmann, 2013). However, findings have focused on the linear relationship between total working capital management and profitability, but not the curvilinear relationship between each component of working capital and firm value (Aktas et al., 2015; Knauer \& Wohrmann, 2013). Examining the relationship of working-capital components to firm value would offer better understanding of the investment levels in working-capital component that maximizes firm value (Aktas et al., 2015; Knauer \& Wohrmann, 2013).

\subsection{Problem Statement}

According to working-capital theory, the efficient management of working capital increases firm value, but additional costs of investment and cost of working-capital management reduces additional investment returns (Atkas et al., 2015; Baños-Caballero et al., 2014; Bhanawat \& Chundawat, 2012; Poornima et al., 2015). The general problem is that current research assumes firm managers know the optimal level of investment in total working capital but fail to consider that firm managers do not know the optimal level of investment in each working-capital component (Afrifa, Tauringana, \& Tingbani, 2015; Knauer \& Wohrmann, 2013). The specific problem addressed is firm managers that do not understand the optimal level for each component of working capital create sub-optimal firm value; leading to diminished investment returns for shareholders (Baños-Caballero et al., 2014; Hill et al., 2012; Kieschnick et al., 2013; Knauer \& Wohrmann, 2013). The over or under investment in working capital can cause increasing bankruptcy risks, loss of sales opportunities, increased debt levels, and lower profitability (de Almeida \& Eid, 2014; Hill et al., 2012; Kieschnick et al., 2013; Knauer \& Wohrmann, 2013).

Researchers have focused on the effects of overall working capital, but they have not identified how the relationship between components of working capital maximize firm value creation (Atkas et al., 2015; Baños-Caballero et al., 2014; Knauer \& Wohrmann, 2013). If firm managers, shareholders, and financing entities are able to determine the effects of working-capital component investment on the value of the firm, the efficient investment of working capital and high returns for investors will become more likely (Atkas et al., 2015; Kieschnick et al., 2013). Determining the extent to which the components of working capital affect firm value could help companies maximize the value created by increasing or decreasing working-capital investment (Atkas et al., 2015; Kieschnick et al., 2013).

The purpose of this quantitative, correlational, archival study was to examine whether a curvilinear relationship exists between accounts receivable, accounts payable, inventory, and firm value in non-financial firms after accounting for firm size, financial distress, debt levels, and growth of sales. We included non-financial firms listed in the Russell 2000 stock index for two consecutive years (eight consecutive quarters). Non-financial firms were selected because the structure of working capital for non-financial companies is different from that of financial firms (Tauringana \& Afrifa, 2013).

This study was designed to contribute to the literature on working capital by examining the financial behavior of firm managers' decisions regarding working-capital management and working-capital investment. This proposed study informs practitioners into determining the curvilinear relationship between accounts receivable, accounts payable, inventory, and firm value (Tauringana \& Afrifa, 2013).

\subsection{Review of Working- Capital Literature}

Firms invest significant amounts of capital in the purchase of inventory (Knauer \& Wohrmann, 2013; Rani, 2013). Selling this inventory to customers of the firm creates accounts receivables and collection of accounts receivable generates cash for the firm (Knauer \& Wohrmann, 2013; Rani, 2013). To fund the purchase of inventory and generate accounts receivable, companies buy product from other companies, which creates payment obligations (accounts payables) to these other firms (Knauer \& Wohrmann, 2013; Rani, 2013). For some companies, especially smaller firms, working capital is the single largest investment (Ek \& Guerin, 2011). The short-term interaction between accounts receivable, accounts payable, and inventory is important because working-capital management must ensure the efficiency of business operations and at the same time generate 
profit (Sharma \& Kumar, 2011). Consequently, working capital theory suggests managers achieve an optimal level of working capital that maximizes firm value (Atkas et al., 2015; Baños-Caballero et al., 2014).

Firm managers must be diligent in understanding the benefits and costs associated with accounts receivable, accounts payable, inventory management (Rani, 2013; Garcia-Teruel \& Martinez-Solano, 2010a). A primary objective of receivables management is to maximize the returns from receivables investment while minimize the risk associated with the receivables (Rani, 2013). Accumulating account receivables generates risks for the firm that includes collection costs, bad debts, and capital costs (Rani, 2013; Garcia-Teruel \& Martinez-Solano, 2010a). Capital costs arise from the time gap between the sale of products and the realized payment for the products (Rani, 2013, Knauer \& Wohrmann, 2013). These additional costs generate from opportunity costs of using internal funds or interest cost of using external financing to generate sales for the firm (Rani, 2013; Garcia-Teruel \& Martinez-Solano, 2010a).

Firms hold inventory for improved production scheduling, minimizing stock-out costs, and reducing purchasing costs by buying in quantity (Basu \& Wang, 2011; Ranganatham; 2011). For any level of sales volume, the amount of working capital required is lower when turning inventory into accounts receivable quickly than when inventory turns into accounts receivable slowly (Ranganatham, 2011). Firms also incur costs associated with inventory including obsolete inventory from inventory surpluses, loss of sales from inventory shortages, variations in unit costs from inconsistent inventory policies, inconsistent invoice payment dates, and shipping fees that increase inventory costs (Basu \& Wang, 2011; Feng et al., 2014; Ranganatham; 2011).

Accounts payable is a form of supplier financing that allows for the purchase of immediate inputs and delayed payment (Hill et al., 2013). Delaying payment allows firms to match incoming payments from their customers to outgoing payment to supplier (Hill et al., 2013). Additionally, financially constrained firms without access to bank credit can still purchase inputs from suppliers (Garcia-Teruel \& Martinez-Solano, 2010b). Financial constrained firms could miss early-pay discounts if offered and suppliers could force firm bankruptcy by denying additional financing because of late payment (Garcia-Teruel \& Martinez-Solano, 2010b; Tauringana \& Afrifa, 2013).

Working-capital theory suggests business managers strive to achieve an optimal level of working capital and move quickly to adjust to these optimal levels via the cash conversion cycle metric (Atkas et al., 2015; Baños-Caballero et al., 2013; Hill et al., 2012; Kieschnick et al., 2013; Sharma \& Kumar, 2011). However, research regarding how firms achieve this optimal level of working capital have been mixed (Baños-Caballero et al., 2014; Baños-Caballero et al., 2013; Knauer \& Wohrmann, 2013; Kieschnick et al, 2013). Regarding a linear relationship between working capital and profitability, some researchers suggest keeping smaller amounts of current assets available increases profitability for firms, whereas other researchers suggest keeping more current assets available to meet liabilities increases profitability and, therefore, firm value (Al-Shabiri, 2011; Ukaegbu, 2014). Additionally, the cash conversion cycle formula suggests keeping less accounts receivable and inventory, while holding more accounts payable (Baños-Caballero et al., 2014; Baños-Caballero et al., 2013; Knauer \& Wohrmann, 2013; Kieschnick et al, 2013). However, research implies that a negative linear relationship exists between accounts receivable, inventory, and profitability, while presenting mixed results regarding accounts payable and profitability (Knauer \& Wohrmann, 2013).

With the exceptions of Atkas et al. (2015) and Baños-Caballero et al. (2014), most studies of working-capital investment have failed to account for the role of diminishing returns in the relationship between working-capital investment and firm value (Baños-Caballero et al., 2014; Knauer \& Wohrmann, 2013). Atkas et al. (2015) and Baños-Caballero et al. (2014) assume that firm managers know how to achieve the optimal level of working capital. However, evidence from linear analysis of working-capital components demonstrate mixed results regarding which component of working capital drives profitability (Al-Shabiri, 2011; Knauer \& Wohrmann, 2013; Tauringana \& Afrifa, 2013; Ukaegbu, 2014). In addition, research has only examined the linear relationship between each component of working capital and profitability, and examining the curvilinear relationship between each working-capital component could provide managers better understanding how to achieve optimal working capital levels that maximize firm value (Knauer \& Wohrmann, 2013).

Firm managers have begun to keep the creation of shareholder wealth in mind as part of the working-capital management process (Bhanawat \& Chundawat, 2012). Previous studies regarding working-capital management have examine the relationship between working capital and profitability (de Almeida, \& Eid, 2014; Hill, Kelly, \& Lockhart, 2012; Kieschnick, Laplante, \& Moussawi, 2013; Knauer \& Wohrmann, 2013; Tauringana \& Afrifa, 2013; Wasiuzzaman, \& Arumugam, 2013). However, recent literature suggests that accounting profit does not adequately represent real firm value creation (Alam \& Nizamuddin, 2012). For continued investment by 
investors and external financiers, value creation becomes important to distinguish good investment opportunities from investment opportunities that destroy wealth (Poornima, Narayan, \& Reddy, 2015).

Working-capital management theory implies that firm managers look for target levels of working capital, and that these target levels of working capital would push managers to achieve certain firm size, growth prospects, and debt levels (Aktas et al., 2015; Baños-Caballero, Garcia-Teruel, \& Martinez-Solano, 2014; Bentzen, Madsen, \& Smith, 2012; Occhino \& Pescatori, 2015). Conversely, increasing debt levels could increase the financial stress on companies from higher interest payments (Cai \& Zhang, 2011). Additionally, investors perceive a dollar already held in cash as more valuable than a dollar invested in working capital (de Almeida \& Eid, 2014; Kieschnick et al., 2013). Researchers have focused on the curvilinear relationship between overall working capital and profitability but have not investigated the curvilinear relationship of investment in each component of working capital to the creation of firm value (Knauer \& Wohrmann, 2013). Each component of working capital affords risks and rewards to firms, and how the firm funds its working-capital structure plays a part in how managers create value for the firm (Aktas et al., 2015; Baños-Caballero et al., 2014). An investigation of a curvilinear relationship would need to account for the cost and benefits of taking on additional debt or internal funding for working-capital investment (Baños-Caballero et al., 2014; Knauer \& Wohrmann, 2013). To achieve an estimate for a curvilinear relationship for each working capital component, accounts receivable, inventory, and accounts payable and the square of each component of working capital needs inclusion for proper examination (Atkas et al., 2015, Baños-Caballero et al., 2014; Knauer \& Wohrmann, 2013). Following the examples of Atkas et al. (2015), Baños-Caballero et al. (2014), including debt levels of the firms, sales growth, firm size, and financial distress would help control for motivational and economic factors that shape the day-to-day decision making for firm managers.

\subsection{Hypotheses}

This study contributed to the literature by examining the value creation of working-capital investment. This study examined the relationship between the three-primary working-capital components (along with the squares of each) and firm value. Examining how the three-primary working-capital components affect firm value could entice suppliers and creditors to fund working-capital investment by providing evidence of firm value creation by managers. In addition, managers focusing on firm value could provide better opportunities for job creation and increased sales growth for firms. Firms focusing on value creation could limit overinvestment in working capital, which in turn could limit future firm liquidity crises caused by inability to access bank provided credit.

Therefore, the following hypotheses for this study are:

H1 A statistically significant curvilinear relationship between accounts receivable and firm value, after accounting for firm size, leverage, financial distress, and sales growth does not exist.

H2. A statistically significant curvilinear relationship between accounts payable and firm value, after accounting for firm size, leverage, financial distress, and sales growth does not exist.

H3. A statistically significant curvilinear relationship between inventory and firm value, after accounting for firm size, leverage, financial distress, and sales growth does not exist.

The purpose of this research study was to examine whether a curvilinear relationship exists between accounts receivable, accounts payable, inventory, and firm value, accounting for accounting for firm size, financial distress, debt levels, and growth of sales. In reviewing the current literature in working-capital management, we found that a gap in the literature existed in involving working-capital components and working-capital management. The remainder of the paper is organized as follows: Section 2 describes the methodology of the study, Section 3 analyzes the reults of the study, and Section 4 summarizes the paper and provides future research topics.

\section{Method}

The data set for this quantitative study included quarterly financial information from publicly traded companies listed on the Russell 2000 stock index. Quarterly data from non-financial firms in the Russell 2000 Index for the years 2003-2012 was collected. The period was chosen to analyze a full economic cycle to examine in the United States (Visan, \& Ailenei, 2013). A full economic cycle for this study consisted of an increase of production of the economy from boom to bust (Visan, \& Ailenei, 2013).

This research study utilized standard data panel analysis to examine the selected data set. Panel data analysis allowed for control of unobservable heterogeneity since firms are heterogeneous and have difficulty measuring characteristics that influence firm value (Baños-Caballero, Garcia-Teruel, \& Martinez-Solano, 2014). Examination of only non-financial firms offered consistent insight into working capital management and firm 
value since financial firms do not have the same working capital structure as non-financial companies (Tauringana \& Afrifa, 2013).

\subsection{Sampling Procedures, Sample Size and Power}

A power and sample size analysis conducted a prior determined a sample size of 101 based on a medium effect size of .15, and alpha significance level of .05 , a power of $80 \%$. We used a stratified random sampling technique to choose 150 firms for the sample population for analysis in this study. The stratum consisted of four industries (Manufacturing, Wholesale Trade, Retail, and Services) based on the Standard Industrial Classification system. Only 147 firms comprised the final sample because we were unable to find consistent information for three of the firms chosen.

The total population of the Russell 2000 as of June 2015 was 1987 . However, only 1497 firms reported accounts receivable, accounts payable, and inventory for which to use in this study. We reduced the total population by removing the firms listed within SIC 6000-6799 to exclude financial firms from the population set. After the removal of financial firms, the remaining 992 firms comprised the final sample population before sampling. The achieved power of the study was calculated from the G*Power program (Faul, Erdfelder, Buchner \& Lang, 2009), assuming a medium effect size of .15 , and alpha significance level of .05 , a power of $80 \%$, and 6 independent variables. Six independent variables were assumed because the three squared variables will each be counted as independent variables, and there are four control variables in addition. The G*Power analysis recommended a sample size of 101 cases based on the effect size, and alpha significance. We used an effect size of .15 to provide analysis that a financial manager could detect if the implementation of the study suggestions occurred (Zahn, 2013).

After applying a stratified random sampling technique, the final sample comprised of 88 firms from the Manufacturing industry, 15 firms from the Retail industry, 41 firms from the Services industry, and 6 firms from the Wholesale Trade industry. We downloaded quarterly observations for the years March 2003 until December 2012 from Sharadar (Sharadar, 2016). The downloaded data set consisted of 5,614 quarterly observations. After removing missing observations, the dataset consisted of 2,275 quarterly observations for 140 sample firms.

\subsubsection{Covariates}

For the purposes of this study, three independent variables for this study were accounts receivable, accounts payable, and inventory. The ten independent variables consisting of accounts receivable, accounts payable, and inventory, growth of sales, firm size, financial distress, leverage, and the squares for accounts receivable, accounts payable, and inventory will be regressed on the criterion variable of firm value. The results were controlled for firm size, the growth of sales, financial distress, and leverage. The definitions of these variables are as follows:

APDO. Accounts payables are goods or services that a firm buys from a supplier and pays the supplier for the goods or services at an agreed upon due date (Baker \& Martin, 2011). The definition of accounts payable for this paper is the days outstanding for each quarter ((accounts payable/cost of sales) *91).

ARDO. Accounts receivable are goods or services that a firm sells to another firm and allows the buying firm to pay for the goods or services at an agreed upon due date (Baker \& Martin, 2011). The operational definition of account receivables is for this paper is the days outstanding for each quarter ((accounts receivable/revenue) $* 91$ ).

ALTMAN_ZSCORE. The Altman Z-Score measures a firm's solvency and is a measure of a firm's financial health (Baños-Caballero et al., 2014). The $\mathrm{Z}$ score is an interval variable designed to predict the probability of financial distress of businesses (Baños-Caballero et al., 2014).

EVA. Economic Value Added is an economic and financial performance measurement tool that closely resembles the real economic profit of the firm (Nicoleta \& Munteanu, 2014). EVA = The Net Operating Result minus the cost of the invested capital. Due to the lack of information to calculate true cost of capital for this study, the calculation originates from the industry average for the firm. Industry averages originate from a dataset from a professor at NYU (Aswath, 2016).

TOTAL_ASSETS. Firm size is a control variable for this study. Larger firms have better access to cheaper external financing than smaller firms do (Hill, Kelly, \& Lockhart, 2012; Atkas et al., 2015). Smaller firms must rely more on internal financing because of a lack of available financial information and increased credit risk assumptions from financial intermediaries (Tauringana \& Afrifa, 2013). Larger firms have better access to credit markets along with having higher profitability (Baños-Caballero et al., 2014). We operationalized firm size as the natural log of total assets (Baños-Caballero et al., 2014). 
SALES_GROWTH. We control for the quarterly growth of sales, since the growth of sales could affect working-capital components and vice versa. Growth of sales is an interval and continuous variable defined as (QSt-QSt-1)/QSt.

INDO. Inventory is purchased goods to either build products or keep stock to sell to other companies (Baker \& Martin, 2011). Businesses use inventory to produce products to turn into accounts receivable or hold for safety stock to limit demand shocks from potential customers. The definition of inventory for this paper is the days outstanding for each quarter ((inventory/cost of sales) $* 91$ ).

LEVERAGE. Leverage describes the amount of liabilities a firm has compared to total assets of the business (Baker \& Martin, 2011). More leverage increases a company's risk of default on repayment of its liabilities. The calculation of Leverage is total debt divided by total assets.

\section{Results}

\subsection{Statistics and Data Analysis}

We performed outlier detection testing on the data due to the wide variation of the sample firms. The decision was made to winsorize the data for outliers by the Tukey method (Q1 $-1.5^{*} \mathrm{IQR}$ and $\left.\mathrm{Q} 3+1.5 * \mathrm{IQR}\right)$ by replacing the extreme outliers with the nearest non-outlier observation (Afrifa, Tauringana, \& Tingbani, 2015). Table 1 describes the descriptive statistics after winsorization of the data (Note 3). The descriptive statistics included the mean, standard deviation, minimum, maximum, the 25 th percentile, and the 75 th percentile.

Table 1. Descriptive statistics

\begin{tabular}{lcccccc}
\multicolumn{7}{c}{ Descriptive Statistics of Sample } \\
\hline Statistic & $\mathrm{N}$ & Min & Max & Mean & Median & St. Dev. \\
\hline ARDO & 2,275 & 1.045 & 121.000 & 50.315 & 51.052 & 27.952 \\
APDO & 2,275 & 4.336 & 87.311 & 41.889 & 36.972 & 20.645 \\
INDO & 2,275 & 1.410 & 229.054 & 90.060 & 76.910 & 59.472 \\
TOTALASSETS & 2,275 & 10.569 & $2,066.169$ & 737.245 & 543.468 & 613.418 \\
EVA & 2,275 & -1.700 & 3.201 & 0.775 & 0.633 & 1.188 \\
SALES_GROWTH & 2,275 & -0.257 & 0.295 & 0.015 & 0.024 & 0.133 \\
LEVERAGE & 2,275 & 0.00003 & 0.744 & 0.237 & 0.194 & 0.195 \\
ALTMAN_ZSCORE 2,275 & -0.675 & 5.007 & 2.215 & 2.035 & 1.145 \\
\hline EVA and TOTALASSETS in millions of dollars & & &
\end{tabular}

The average firm for this sample collects accounts receivables in 50 days, while selling its inventory in 90 days, paying its suppliers in 42 days, and creating 774,623 dollars in firm value per quarter. The average sales growth for firms in this study was $2 \%$, leverage of $24 \%$, total assets of roughly 737 million dollars, and Altman's ZScore of 2.22 (Note 1).

Figure 1 provides a graphical depiction of the median accounts receivable days outstanding (ARDO), accounts payable days outstanding (APDO), and inventory days outstanding (INDO) for the sample by quarters (Note 2). Figure 2 represents the median Economic Value Added (EVA) over the period of the study (Note 2).

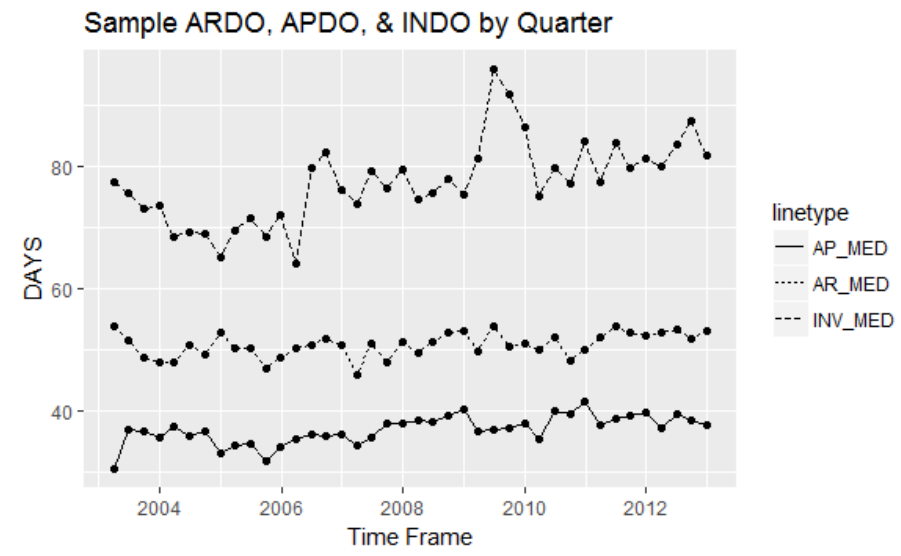

Figure 1. Sample ARDO, APDO, and INDO by quarter 


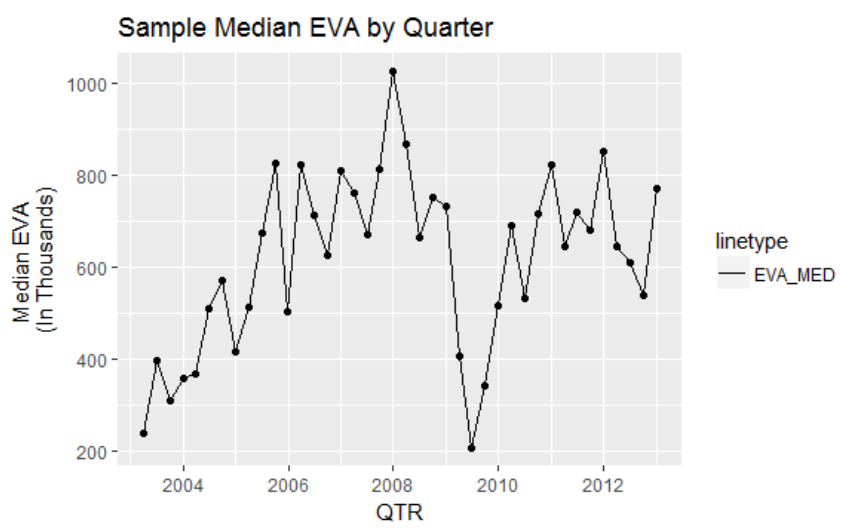

Figure 2. Sample median EVA by quarter

Figure 1 depicts an increasing trend for median APDO and INDO over the sample period, while ARDO remained within a flat trend. Figure 2 describes a curvilinear trend for the median EVA for the sample period. The median EVA increase until 2008, then decreasing below the median EVA in 2003, then increasing to EVA levels of 2006.

\subsection{Analysis Results}

We performed a spearman correlation analysis on the independent and dependent variables for examination of multicollinearity. Multicollinearity can lead to the misspecification of the regression results (Field, 2005). According to Field (2005), multicollinearity presents when correlation coefficients exceed .8.

Table 2. Correlation analysis with significance

\begin{tabular}{|c|c|c|c|c|c|c|c|}
\hline & ARDO & APDO & INDO & TOTALASSETS & EVA & SALES_GROWTH & LEVERAGE \\
\hline \multicolumn{8}{|l|}{ ARDO } \\
\hline APDO & $0.27^{* * *}$ & & & & & & \\
\hline INDO & $0.28^{* * *}$ & $0.50^{* * *}$ & & & & & \\
\hline TOTALASSETS & $-0.11 * * *$ & $-0.24 * * *$ & $-0.27 * * *$ & & & & \\
\hline EVA & $-0.16 * * *$ & $-0.28 * * *$ & $-0.29 * * *$ & $0.57 * * *$ & & & \\
\hline SALES_GROWTH & -0.03 & -0.01 & $-0.08 * * *$ & 0 & $0.18^{* * *}$ & & \\
\hline LEVERAGE & $-0.34 * * *$ & $-0.16^{* * * *}$ & $-0.22 * * *$ & $0.36^{* * * *}$ & $0.21 * * *$ & -0.01 & \\
\hline ALTMAN_ZSCORE & $0.31 * * *$ & 0.02 & $0.32 * * *$ & $-0.36 * * *$ & $-0.13 * * *$ & 0.03 & $-0.82 * * *$ \\
\hline
\end{tabular}

Table 2 provides evidence that only correlation coefficient between Leverage (LEV) and Altman's Z Score (ALTMAN_ZSCORE) exceed the .8 threshold for the sample (Note 3). Moreover, a low correlation coefficient does not imply lack of multicollinearity since the correlation matrix only considers the bivariate correlations between variables (Mason \& Perreault, 1991). Since the correlation coefficient for Leverage and Altman's Z-Score exceed the .8 threshold suggested by Field (2005), we performed variance inflation factor analysis on the three regression models (ARDO, APDO, and INDO).

Table 3. Generalized variance inflation factors for AR

\begin{tabular}{llll}
$\begin{array}{c}\text { Generalized Variance Inflation Factors } \\
\text { for AR }\end{array}$ \\
\hline \multicolumn{3}{c}{ GVIF Df GVIFDf)) } \\
\hline poly(ARDO, 2) & 1.187 & 2 & 1.044 \\
SALES_GROWTH & 1.004 & 1 & 1.002 \\
TOTALASSETS & 1.122 & 1 & 1.059 \\
LEVERAGE & 2.629 & 1 & 1.622 \\
ALTMAN_ZSCORE & 2.515 & 1 & 1.586 \\
\hline
\end{tabular}


Table 4. Generalized variance inflation factors for AP

\begin{tabular}{|c|c|c|}
\hline \multicolumn{3}{|c|}{$\begin{array}{c}\text { Generalized Variance Inflation Factors } \\
\text { for AP }\end{array}$} \\
\hline & GVIF Df & GVIFDf)) \\
\hline poly(APDO, 2) & 1.2102 & 1.049 \\
\hline SALES_GROWTH & 1.0021 & 1.001 \\
\hline TOTALASSETS & 1.2051 & 1.098 \\
\hline LEVERAGE & 2.6911 & 1.640 \\
\hline ALTMAN ZSCORE & 2.7191 & 1.649 \\
\hline
\end{tabular}

Table 5. Generalized variance inflation factors for INV

\begin{tabular}{|c|c|c|}
\hline \multicolumn{3}{|c|}{$\begin{array}{c}\text { Generalized Variance Inflation Factors } \\
\text { for INV }\end{array}$} \\
\hline & GVIF Df & sVIFDf)) \\
\hline poly(INDO, 2) & 1.1892 & 1.044 \\
\hline SALES_GROWTH & 1.0111 & 1.005 \\
\hline TOTALASSETS & 1.1901 & 1.091 \\
\hline LEVERAGE & 2.4081 & 1.552 \\
\hline ALTMAN_ZSCORE & 2.5741 & 1.604 \\
\hline
\end{tabular}

Table 3 depicts the generalized variance inflation factors for EVA regressed on accounts receivable days outstanding and the control variables. Table 4 presents the generalized variance inflation factors for EVA regressed on accounts payable days outstanding and the control variables. Lastly, Table 5 describes the generalized variance inflation factors for EVA regressed on inventory days outstanding and the control variables. Since none of the generalized variance inflation factors are greater than 10, as suggested by Field (2005), multicollinearity is not an issue for the sample variables. We performed regression analysis for the dependent variable economic value added compared to the control variables (growth of sales, leverage, financial constraints, and company size) and accounts receivable, accounts payable, and inventory.

Table 6. Regression analysis for AR, AP, and INV

\begin{tabular}{|c|c|c|c|}
\hline & \multicolumn{3}{|c|}{ Dependent variable: } \\
\hline & \multicolumn{3}{|c|}{ EVA } \\
\hline & $\mathrm{AR}$ & $\mathrm{AP}$ & INV \\
\hline & (1) & (2) & (3) \\
\hline \multirow[t]{2}{*}{ Constant } & $-12,302,533.00^{* * *}$ & $-11,929,913.00^{* * *}$ & $-11,889,967.00^{* * * *}$ \\
\hline & $\mathrm{t}=-31.30$ & $\mathrm{t}=-27.38$ & $t=-28.66$ \\
\hline \multirow[t]{2}{*}{ poly(ARDO, 2)1 } & $-6,542,815.00^{* * *}$ & & \\
\hline & $\mathrm{t}=-7.34$ & & \\
\hline \multirow[t]{2}{*}{ poly(ARDO, 2)2 } & $2,508,071.00^{* * *}$ & & \\
\hline & $\mathrm{t}=3.02$ & & \\
\hline \multirow[t]{2}{*}{ poly(APDO, 2)1 } & & $-3,027,943.00^{* * *}$ & \\
\hline & & $\mathrm{t}=-3.23$ & \\
\hline \multirow[t]{2}{*}{ poly(APDO, 2)2 } & & $1,557,292.00^{*}$ & \\
\hline & & $\mathrm{t}=1.83$ & \\
\hline \multirow[t]{2}{*}{ poly(INDO, 2)1 } & & & $-5,074,003.00^{* * *}$ \\
\hline & & & $\mathrm{t}=-5.54$ \\
\hline \multirow[t]{2}{*}{ poly(INDO, 2)2 } & & & $1,513,173.00^{*}$ \\
\hline & & & $\mathrm{t}=1.80$ \\
\hline \multirow[t]{2}{*}{ SALES_GROWTH } & $1,760,149.00^{* * * *}$ & $1,793,328.00^{* * * *}$ & $1,731,358.00^{* * *}$ \\
\hline & $t=12.03$ & $\mathrm{t}=12.14$ & $\mathrm{t}=11.74$ \\
\hline
\end{tabular}




\begin{tabular}{llll}
\hline $\log ($ TOTALASSETS $)$ & $637,438.70^{* * *}$ & $619,790.80^{* * *}$ & $609,011.90^{* * *}$ \\
& $\mathrm{t}=33.79$ & $\mathrm{t}=30.13$ & $\mathrm{t}=30.32$ \\
LEVERAGE & $307,612.90^{* *}$ & $459,445.00^{* * *}$ & $664,406.80^{* * *}$ \\
& $\mathrm{t}=1.99$ & $\mathrm{t}=2.90$ & $\mathrm{t}=4.47$ \\
ALTMAN_ZSCORE & $119,804.60^{* * *}$ & $94,569.47^{* * *}$ & $153,022.20^{* * *}$ \\
& $\mathrm{t}=4.50$ & $\mathrm{t}=3.34$ & $\mathrm{t}=5.65$ \\
Observations & 2,275 & 2,275 & 2,275 \\
$\mathrm{R}^{2}$ & 0.40 & 0.38 & 0.39 \\
Adjusted $\mathrm{R}^{2}$ & 0.40 & 0.38 & 0.39 \\
Residual Std. Error $(\mathrm{df}=2268)$ & $824,358.20$ & $832,793.60$ & $829,024.60$ \\
F Statistic $(\mathrm{df}=6 ; 2268)$ & $249.17^{* * *}$ & $236.52^{* * *}$ & $242.12^{* * *}$ \\
\hline
\end{tabular}

Note. ${ }^{*} \mathrm{p}<0.1 ;{ }^{* *} \mathrm{p}<0.05 ;{ }^{* * *} \mathrm{p}<0.01$.

Table 6 presents the results of the three models (Note 3). In regression model 1, there is a statistically significant negative relationship between accounts receivable days outstanding $(\mathrm{p}<.01)$ and economic value added. A negative sign for accounts receivable days outstanding suggests that economic value-added increases as accounts receivable days outstanding decreases toward zero. The sign for accounts receivable days outstanding squared ( $\mathrm{p}$ $<.01)$ is statistically significantly positive, suggesting a leveling of the negative trend over time. Sales growth $(\mathrm{p}<.01)$, the natural log of total assets $(\mathrm{p}<.01)$, leverage ( $<<.05)$, and Altman's Z-Score $(\mathrm{p}<.01)$ have statistically significant positive signs. The six variables in model 1 accounted for $40 \%$ of the variance in firm value, $\mathrm{F}(6$, 2268), $\mathrm{p}<.01, \mathrm{R} 2=.40$.

Regression model 2 accounts for $38 \%$ of the variance in economic value added, $F(6,2268), p<.01, R 2=.38$. There is a statistically significant negative relationship between accounts payable days outstanding $(\mathrm{p}<.01)$ and economic value added. The sign for accounts payable days outstanding squared is statistically significantly positive at the $10 \%$ level $(\mathrm{p}<.1)$. As stated in regard to model 1 , a positive sign for the square of accounts payable outstanding implies a positive trend takes shape over time. Sales growth $(\mathrm{p}<.01)$, natural $\log$ of total assets $(\mathrm{p}<.01)$, leverage $(\mathrm{p}<.01)$, and Altman's Z-Score $(\mathrm{p}<.01)$ have statistically significant positive relationships with economic value added. Economic value-added increase when the four control variables in model 2 increase.

Lastly, regression model 3 indicates a negative statistically significant relationship between economic value added and inventory days outstanding $(\mathrm{p}<.01)$. Again, a negative sign for inventory days outstanding indicates that economic value-added increases as inventory days outstanding decrease. A statistically significant relationship between inventory days outstanding square $(\mathrm{p}<.1)$ and economic value added exists. The positive sign for the square of inventory days outstanding suggests a decelerating negative trend at some point in time. The control variables are the same in regression model 3 as used previously in the first two models. All four control variables have positive signs and are statistically significant at the $1 \%$ level $(\mathrm{p}<.01)$. The six variables in regression model 3 account for $39 \%$ of the variance in economic value added, $F(6,2268), \mathrm{p}<.01, \mathrm{R} 2=.39$.

\subsection{Evalutation of Results}

\subsubsection{Relationship between Accounts Recievable and Firm Value}

The first research question addresses where a curvilinear relationship exists between accounts receivable and firm value while accounting for firm size, financial distress, debt levels, and growth of sales. The results indicate that there is a significant curvilinear relationship between accounts receivable and firm value, $F(6,2268), p<.01$, $\mathrm{R}^{2}=.40$. The null hypothesis (H10) is rejected and the alternate hypothesis (H1a) of a statistically significant curvilinear relationship between accounts receivable and firm value, after accounting for firm size, leverage, financial distress, and sales growth does exist was accepted. Accounts receivable, its square, financial distress, debt levels, and growth of sales accounted for $40 \%$ of the variance in firm value.

This finding of a curvilinear relationship is parallel to findings such as Baños-Caballero et al. (2014), Afrifa et al. (2015), and Atkas et al. (2015). The results of this study differ from Baños-Caballero et al. (2014) and Afrifa et al. (2015) since the results of this study show a minimizing point at which investment in accounts receivables does not increase firm value. Afrifa et al. (2015) indicated a maximizing point where increasing investment in accounts receivable decreases firm value. It is noteworthy that the study performed by Afrifa et al. (2015) examined small to medium sized firms in the United Kingdom, while the present study examined larger firms listed on a highly-traded index in the United States. The present study results signify that keeping accounts 
receivables days outstanding as low as practical does improve firm value, which are similar results as Deloof (2003), Gill et al. (2010), and Ukaegbu (2014). While a curvilinear relationship between accounts receivable and firm value, we found a minimizing curve instead of a maximizing curve as reported in Afrifa et al. (2015).

\subsubsection{Relationship between Accounts Payable and FirmValue}

The second research question addresses whether a curvilinear relationship exists between accounts payable and firm value while accounting for firm size, financial distress, debt levels, and growth of sales. The results indicate that there is a significant curvilinear relationship between accounts receivable and firm value, $F(6,2268), p<.01$, $\mathrm{R} 2=.38$. The null hypothesis $(\mathrm{H} 20)$ is rejected and the alternate hypothesis $(\mathrm{H} 2 \mathrm{a})$ of a statistically significant curvilinear relationship between accounts receivable and firm value, after accounting for firm size, leverage, financial distress, and sales growth does exist was accepted.

The study results are similar to results found by Afrifa et al. (2015). Conversely, the direction of the curvilinear relationship is inverse from the study performed by Afrifa et al. (2015). Positive signs for the four control variables indicate that as these four variables increase, a company will have an increase in firm value. The study results indicate firms that pay faster (taking discounts for early payment) increase firm value. Results from this study emulate the negative relationship between accounts payable and firm profitability report by Deloof (2003), Gill et al. (2010), Tauringana and Afrifa (2013), and Ukaegbu (2014).

\subsubsection{Relationship between Inventory and Firm Value}

The final research question addresses whether a curvilinear relationship exists between inventory and firm value while accounting for firm size, financial distress, debt levels, and growth of sales. The results indicate that there is a significant curvilinear relationship between accounts receivable and firm value, $\mathrm{F}(6,2268), \mathrm{p}<.01, \mathrm{R} 2=.39$. The null hypothesis (H30) is rejected and the alternate hypothesis (H3a) of a statistically significant curvilinear relationship between accounts receivable and firm value, after accounting for firm size, leverage, financial distress, and sales growth does exist was accepted.

As stated regarding accounts receivable and accounts payable, a statistically significant curvilinear relationship between inventory and firm value. The results of the study show a similar negative relationship between inventory and firm value as Sharma and Kumar (2011), Deloof (2003), and Ukaegbu (2014). Conversely, Sharma and Kumar (2011), Deloof (2003), and Ukaegbu (2014) only examined a linear relationship while this study found a minimizing point between inventory and firm value. Afrifa et al. (2015) found a maximizing curvilinear relationship between inventory and firm value, while we found a minimizing curvilinear relationship. The results indicate firms that lower inventory increase the value of the firm.

\section{Discussion}

The problem addressed for this study was firm managers not considering the diminishing returns of investment into accounts receivable, accounts payable, and inventory do not maximize firm value, which diminishes investment returns for shareholders (Baños-Caballero et al., 2014; Hill et al., 2012; Kieschnick et al., 2013; Knauer \& Wohrmann, 2013). Over or under investing in working capital can lead to increasing debt levels, higher bankruptcy risks, loss of sales opportunities, and lower profitability for firms (de Almeida \& Eid, 2014; Hill et al., 2012; Kieschnick et al., 2013; Knauer \& Wohrmann, 2013). Determining the extent to which the components of working capital affect firm value could help companies maximize the value created by increasing or decreasing working-capital investment (Atkas et al., 2015; Kieschnick et al., 2013). The purpose of this quantitative, correlational archival study was to examine whether a curvilinear relationship exists between accounts receivable, accounts payable, inventory, and firm value in non-financial firms after accounting for firm size, financial distress, debt levels, and growth of sales. A correlation/regression analysis was used to answer the three research questions presented for this study. We examined 140 firms using a stratified random sample of the non-financial firms listed on the Russell 2000 index.

Several limitations existed for this study. Since the study included financial constraints as a control variable, survival bias could limit the applicability of the study to firms that did not survive during the years of study. Additionally, differing economic conditions could have biased the study in regard to the independent working-capital variables and could affect the direction of the curvilinear relationship. Conversely, the U-shaped relationships found between firm value, accounts receivable, accounts payable, and inventory could also be a side effect of including the years 2007-2009.

The findings presented in this study suggest that a curvilinear relationship exists between accounts receivable, accounts payable, inventory, and firm value, while accounting for firm size, financial distress, firm debt levels, and growth of sales. The findings of this study suggest firm managers adjust accounts receivable, accounts 
payable, and inventory levels in search of an optimal level of working capital.

Regarding practical applications, firm managers should manage each individual working-capital component separately to increase firm value, since a neutralizing effect may exist with the cash conversion cycle. It is also recommended that firm managers keep accounts receivable, accounts payable, and inventory days as low as practical to increase firm value, but firm value will increase by increasing accounts receivable, accounts payable, and inventory days outstanding when economic or business conditions worsen. To keep accounts receivable days low, firms should implement restrictive customer credit policies when economic conditions are good to collect monies faster, while relaxing credit policies for customer when economic times are difficult for customers. It is recommended that firms take early pay discounts when business and economic conditions allow, which would lower account payable days, while attempting to match inbound sales with outbound payments when business and economic conditions worsen. The same recommendation should be followed for inventory days outstanding as accounts payable and accounts receivable days outstanding.

\subsection{Future Research}

Consideration for future quantitative research into working-capital management and firm value should consider whether different curvilinear relationships exist between firm value and working-capital components during different economic cycles. In addition, future quantitative research should examine whether short-term borrowings need to be included into the cash conversion cycle. Including short-term borrowing in the cash conversion cycle could provide additional insight into whether firms using both accounts payable and banking lines of credit have curvilinear relationships with firm value and whether the current cash conversion-cycle measurement warrants adjustment. Another possible avenue for qualitative research includes surveying firm managers to understand which working capital component is more important in driving firm value. Finally, introducing research that examines whether including the lag of accounts receivable, accounts payable, and inventory investment provides any additional insight into whether increasing or decreasing investment into working capital changes firm value.

\section{References}

Afrifa, G. A., Tauringana, V., \& Tingbani, I. (2015). Working capital management and performance of listed SMEs. Journal of Small Business \& Entrepreneurship, 27(6), 557-578. https://doi.org/10.1080/08276331.2015.1114351

Aktas, N., Bodt, E., Lobez, F., \& Statnik, J. (2012). The information content of trade credit. Journal of Banking \& Finance, 36(5), 1402-1413. https://doi.org/10.1016/j.jbankfin.2011.12.001

Aktas, N., Croci, E., \& Petmezas, D. (2015). Is working-capital management value-enhancing? Evidence from firm performance and investments. Journal of Corporate Finance, 30, 98-113. https://doi.org/10.1016/j.jcorpfin.2014.12.008

Alam, P., \& Nizamuddin, M. (2012). Performance measures of shareholders wealth: An application of economic value added (eva). International Journal of Applied Financial Management Perspectives, 1(2), 160-166.

Aswath, D. (2016). http://pages.stern.nyu.edu/ adamodar/New_Home_Page/datafile/wacc.htm

Baños-Caballero, S., García-Teruel, P. J., \& Martínez-Solano, P. (2010). Working capital management in SMEs. Accounting \& Finance, 50(3), 511-527. https://doi.org/10.1111/j.1467-629X.2009.00331.x

Baños-Caballero, S., García-Teruel, P., \& Martínez-Solano, P. (2013). The speed of adjustment in working capital requirement. The European Journal of Finance, 19(10), 978-992, https://doi.org/10.1080/1351847X.2012.691889

Baños-Caballero, S., García-Teruel, P., \& Martínez-Solano, P. (2012). How does working-capital management affect the profitability of Spanish SMEs?. Small Business Economics, 39(2), 517-529. https://doi.org/10.1007/s11187-011-9317-8

Basu, N., \& Wang, X. (2011). Evidence on the relation between inventory changes, earnings, and firm value. The International Journal of Business and Finance Research, 5(3), 1-14.

Bentzen, J., Madsen, E., \& Smith, V. (2012). Do firms' growth rates depend on firm size? Small Business Economics, 39(4), 937-947. https://doi.org/10.1007/s11187-011-9341-8

Bhanawat, S. S., \& Chundawat, D. S. (2012). Prediction of shareholders' wealth: A quantitative analysis. IUP Journal of Accounting Research \& Audit Practices, 11(3), 7-16.

Cai, J., \& Zhang, Z. (2011). Leverage change, debt overhang, and stock prices. Journal of Corporate Finance, 
17(Financial Flexibility and Corporate Liquidity), 391-402. https://doi.org/10.1016/j.jcorpfin.2010.12.003

De Almeida, J. R., \& Eid, J. W. (2014). Access to finance, working-capital management and company value: Evidences from Brazilian companies listed on BM\&FBOVESPA. Journal of Business Research, 67924-934. https://doi.org/10.1016/j.jbusres.2013.07.012

Deloof, M. (2003). Does working-capital management affect profitability of Belgian firms? Journal of Business, Finance and Accounting, 30, 573-587. https://doi.org/10.1111/1468-5957.00008

Ek, R., \& Guerin, S. (2011). Is there a right level of working capital?. Journal of Corporate Treasury Management, 4(2), 137-149.

Enqvist, J., Graham, M., Nikkinen, J. (2014). The impact of working-capital management on firm profitability in different business cycles: Evidence from Finland. Research in International Business \& Finance [serial online], 32-36. https://doi.org/10.1016/j.ribaf.2014.03.005

Faul, F., Erdfelder, E., Buchner, A., \& Lang, A. G. (2009). Statistical power analyses using G*Power 3.1: Tests for correlation and regression analyses. Behavior Research Methods, 41, 1149-1160. https://doi.org/10.3758/BRM.41.4.1149

Field, A. (2005). Discovering Statistics Using SPSS (2nd ed.). London: Sage.

García-Teruel, P. J., \& Martínez-Solano P. (2010a). A dynamic approach to accounts receivable: A study of $\begin{array}{llll}\text { spanish SMEs. European } & \text { Financial }\end{array}$ https://doi.org/10.1111/j.1468-036X.2008.00461.x

García-Teruel, P. J., \& Martínez-Solano, P. (2010b). A dynamic perspective on the determinants of accounts payable. Review of Quantitative Finance \& Accounting, 34(4), 439-457. https://doi.org/10.1007/s11156-009-0124-0

Hill, M. D., Kelly, G., \& Lockhart, G. (2012). Shareholder returns from supplying trade credit. Financial Management, 4l(1), 255-280. https://doi.org/10.1111/j.1755-053X.2012.01198.x

Hlavac, M. (2015). Stargazer: Well-Formatted Regression and Summary Statistics Tables. R package version 5.2. Retrieved from http://CRAN.R-project.org/package=stargazer

Jang, S., \& Park, K. (2011). Inter-relationship between firm growth and profitability. International Journal of Hospitality Management, 30, 1027-1035. https://doi.org/10.1016/j.ijhm.2011.03.009

Jianzhou, Z., \& Ye, Y. (2013). Why do profitable firms use less debt?. International Journal of Business, Accounting, \& Finance, 7(1), 140.

Kieschnick, R., Laplante, M., \& Moussawi, R. (2013). Working-capital management and shareholders' wealth. Review of Finance, 17(5), 1827-1852. https://doi.org/10.1093/rof/rfs043

Knauer, T., \& Wöhrmann, A. (2013). Working-capital management and firm profitability. Journal of Management Control, 24(1), 77. https://doi.org/10.1007/s00187-013-0173-3

Lee, S. (2014). The relationship between growth and profit: Evidence from firm-level panel data. Structural Change and Economic Dynamics, 281-11. https://doi.org/10.1016/j.strueco.2013.08.002

Mason, C. H., \& Perreault Jr., W. D. (1991). Collinearity, power, and interpretation of multiple regression analysis. Journal of Marketing Research (JMR), 28(3), 268-280. https://doi.org/10.2307/3172863

Mergent Online. (2015). Company Data. Retrieved on August 22, 2015 from http://www.mergentonline.com/noticescm.php?pagetype=about\#U.S.

Nicoleta, G. C., \& Munteanu, V. (2014). The added economic value - an instrument for the performance measurement. Economics, Management \& Financial Markets, 9(4), 167-174.

Occhino, F., \& Pescatori, A. (2015). Debt overhang in a business cycle model. European Economic Review, 7358-84. https://doi.org/10.1016/j.euroecorev.2014.11.003

Poornima B., G., Narayan, P., \& Reddy, Y. V. (2015). Economic value-added as an emerging tool of performance measurement: Evidence from Indian companies. IUP Journal of Accounting Research \& Audit Practices, 14(3), 38 .

R Core Team (2015). R: A language and environment for statistical computing. R Foundation for Statistical Computing, Vienna, Austria. Retrieved from https://www.R-project.org/

Ranganatham, G. (2011). Inventory management (im) practices in small scale enterprises. Global Management 
Review, 5(2), 15-32.

Rani, A. (2013). Management of working capital. International Journal of Computer Science \& Management Studies, 13(3), 85.

Sharma, A., \& Kumar, S. (2011). Effect of working-capital management on firm profitability. Global Business Review, 12(1), 159. https://doi.org/10.1177/097215091001200110

Tauringana, V., \& Afrifa, G. A., (2013). The relative importance of working-capital management and its components to SMEs' profitability. Journal of Small Business and Enterprise Development, 20(3), 453-469. https://doi.org/10.1108/JSBED-12-2011-0029

Ukaegbu, B. (2014). The significance of working-capital management in determining firm profitability: Evidence from developing economies in Africa. Research in International Business and Finance, 311-16. https://doi.org/10.1016/j.ribaf.2013.11.005

Visan, C., \& Ailenei, D. (2013). Forecasting of the economic crisis using business cycles patterns. Theoretical \& Applied Economics, 20(10), 97-110.

Wasiuzzaman, S., \& Arumugam, V. C. (2013). Determinants of working capital investment: A study of Malaysian public listed firms. Australasian Accounting Business \& Finance Journal, 7(2), 49-69. https://doi.org/10.14453/aabfj.v7i2.5

Wickham, H. (2009). ggplot2: Elegant Graphics for Data Analysis. Springer-Verlag New York, 2009. https://doi.org/10.1007/978-0-387-98141-3

\section{Notes}

Note 1. Calculations to create variables of accounts receivables days' outstanding, accounts payable days outstanding, inventory days outstanding, Altman's Z score, leverage, growth of sales, and EVA were performed using the R statistical software (R Core Team, 2015).

Note 2. Figure 1 and Figure 2 were built using the ggplot2 package by H. Wickham (2009) in the R statistical program.

Note 3. Table1, Table 3, Table 4, Table 5, and Table 6 were built using the stargazer package by Hlavac (2015) in the R statistical program.

\section{Copyrights}

Copyright for this article is retained by the author(s), with first publication rights granted to the journal.

This is an open-access article distributed under the terms and conditions of the Creative Commons Attribution license (http://creativecommons.org/licenses/by/4.0/). 